\title{
Electoral Rules and Legislators' Personal Vote-Seeking
}

\author{
Audrey André, André Freire* \& Zsófia Papp
}

\begin{abstract}
Legislators' behaviour in and outside parliament is shaped most crucially by the electoral rules. Existing studies literature linking electoral systems, personal vote-seeking incentives, and legislative behaviour, however, have been hindered by the lack of comparative data and 'direct evidence of a personal vote' (Shugart 2008: 46). This chapter conducts a systematic, two-step analysis of how electoral systems affect the representational role and behaviour of legislators using data from the PARTIREP MP survey. In the first step, we test the impact of different electoral system characteristics (i.e. ballot structure and district magnitude) upon the incentives to cultivate a personal vote as legislators perceive them. In line with Zittel and Gschwend's (2008) notion of 'campaign norms', legislators were asked to assess the relative utility of personal compared to party campaigns in attaining re-election. In the second step, the chapter uses this arguably more direct measurement of personal vote-seeking incentives as a mediator variable to explain the impact formal electoral rules have on two oft-cited indicators of personal and partisan vote-seeking: legislators' commitment to constituency service and to upholding party discipline.
\end{abstract}

\footnotetext{
* As national director of the national branch of the PARTIREP project in Portugal, André Freire gratefully acknowledges the support of both all the sponsors of the project "Portuguese MPs in Comparative Perspective: Elections, Leadership and Political Representation", 2007-2010 (Portuguese Foundation for Science and Technology - FCT -, Portuguese Parliament, Ministry of Internal Affairs - Department for Electoral Administration, Gulbenkian Foundation, National Electoral Commission), for their logistic and financial support, and the Portuguese MPs that participated in the web survey, for their cooperation. A new Portuguese research project on political representation is still going on, 2012-2015: "Elections, Leadership and Accountability: Political Representation in Portugal in a Longitudinal and Comparative Perspective (FCT project reference: “PTDC/CPJ-CPO/119307/2010”).
} 


\section{Introduction}

Electoral institutions, it has commonly been argued, shape the behaviour, attitudes, and orientations of Members of Parliament. Legislators, Mayhew (1974) famously observed, are foremost driven by the desire to retain their seat in parliament - a necessary condition for achieving other, more intrinsically valuable goals (see also Fenno 1978). The focus of legislators' 'permanent campaign' (Blumenthal 1980; Butler and Collins 2001) is, however, affected by the electoral institutions they compete under for re-election. Mayhew's (1974) Congressional study on the 'electoral connection' has inspired a vast body of literature exploring the manner in which electoral institutions affect what legislators do in parliament and beyond. Electoral institutions, Carey and Shugart (1995) specified, determine the relative value of personal and party reputations to legislators in securing re-election and thereby restrict the range of vote-seeking strategies they can successfully pursue. Individualized campaign strategies may translate into (at least) two personal vote-seeking actions: constituency service and dissent from the party line. On the one hand, legislators can develop a reputation of good constituency members by helping individual constituents with their demands for casework and by advocating the constituency's collective economic and social needs (e.g. Searing 1994). On the other hand, legislators may feel the need to differentiate themselves from their parliamentary party by taking positions countering party stands or even by voting against their party on issues that are salient to constituents (especially when government survival is not at stake) (e.g. Carey 2007).

Besides suffering from an Anglo-American bias, most existing studies dealing with the connection between electoral rules, member attitudes and behaviour are either theoretical (e.g. Carey and Shugart 1995) or are case studies in which electoral rules are a constant rather than 
a variable (e.g. Fenno 1978; Cain, Ferejohn, and Fiorina 1987). Comparative studies are scarce and often include a very limited number of cases with only slightly diverse electoral systems (e.g. Heitshusen, Young, and Wood 2005; Pilet, Freire, and Costa 2012). In addition, the current literature linking electoral systems, personal vote-seeking incentives, and legislative behaviour has been hindered by the lack of 'direct evidence of a personal vote' (Shugart 2008, 46). Empirical studies typically go directly from the electoral rules to various often aggregate-level - proxies. The effect electoral rules have on any single indicator tends to be obfuscated by the simple fact that legislators trade off a wide variety of activities contributing to a personal vote (André and Depauw 2013).

Aiming to address these shortcomings in the current literature, this chapter performs a systematic, two-step analysis of how electoral systems affect legislators' attitudes of unprecedented scale using data from the PARTIREP comparative legislators' survey. In the first step, we test the impact of different electoral system features on the incentives to cultivate a personal vote as legislators perceive them. In line with Zittel and Gschwend's (2008) notion of 'campaign norms', legislators were asked to assess the relative utility of personal compared to party campaigns in attaining re-election. In the second step, the chapter uses this arguably more direct measurement of personal vote-seeking incentives as a mediator variable to explain the impact formal electoral rules have on two oft-cited indicators of personal and partisan vote-seeking: legislators' commitment to constituency representation and to upholding party discipline. The findings clearly establish that the type of electoral system has a significant impact on the person or party-centred character of the vote-seeking strategies legislators pursue: personal vote-seeking is strongest in strong preferential systems and/or systems with small districts (in at least one tier), whereas it is weakest in closed-list systems and/or systems with large districts. Constituency service and dissent in parliament, the analysis demonstrates, 
are two common ways to cultivate a personal reputation among constituents. Now, before turning to the two-step analysis in sections four and five, the theoretical foundations are discussed, more precise hypotheses are formulated and the data are presented.

\section{Theoretical framework and expectations}

Most existing typologies classify electoral rules based on the electoral formulae distinguishing between majoritarian and proportional representation (PR) systems (see e.g. Farrell 2001). But, Carey and Shugart (1995) famously argued that the relative value of personal compared to party reputations in securing re-election depends critically on the openness of the electoral system, which is strongly connected with the way voters' options are structured on the ballot. Ceteris paribus, legislators' personal vote-seeking incentives will be stronger in system that allow voters to express a preference for individual candidates than in systems that only allow them to endorse the party list as a whole (Bowler and Farrell 1993; Carey and Shugart 1995). Based on the choices voters face in the voting booth and the effectiveness of preferential voting in determining which candidates are elected, four basic types of electoral systems can be distinguished: non-preferential systems, mixed-member systems, strong preferential systems, and weak preferential systems. Constituency-oriented actions, as a result, should be more common in the presence of intra-party candidate choice than in the absence.

Legislators' incentives to nurture a personal reputation among constituents are weakest in non-preferential systems. Voters can only endorse the party ticket and are not offered the opportunity to express a preference for one or more co-partisan candidates. Under these circumstances, the (re-)election prospects of candidates are inextricably tied to their party's 
electoral performance. Elected representatives will concentrate on strengthening the party's collective reputation for the party leaders entrusted with the selection and ranking of candidates are typically considered their primary principals (Bowler and Farrell 1993; Carey and Shugart 1995). Only in low-magnitude districts legislators may still have an incentive to pursue individualized campaigns: by putting a face to the party, a legislator may draw additional votes to the party and in turn increase his own probability of maintaining a seat in parliament (Shugart 2008). The category of non-preferential systems comprises closed-list PR systems, as well as single-member plurality or majority systems (Carey and Shugart 1995). In neither system can a vote for a candidate be separated from a vote for the party (Karvonen 2004). Voters can only sanction individual legislators at the high cost of changing party affiliation (Mitchell 2000).

Mixed-members systems are classified as a distinctive type of non-preferential system. Although mixed systems encompass quite some institutional variation ${ }^{1}$, they all have (at least) two separate overlapping tiers: one tier must entail allocation of seats nominally whereas seats in the other tiers must be allocated by proportional representation from party lists (Shugart and Wattenberg 2001, 10). On the one hand, these systems are often characterized as the 'best of both worlds'. That is, the incentive structure facing legislators elected in the PR and SMD tiers are assumed not to differ from those in pure closed-list and single-member plurality/majority systems (e.g. Lancaster 1986). On the other hand, scholars increasingly point at spill-over or contamination effects as a result of combining several tiers. It is the assumption that political actors in mixed systems respond strategically to the unique competing incentives generated by the majoritarian and proportional components (Herron and Nishikawa 2001; Cox and Schoppa 2002). In particular, the relative value of personal and party reputations depends on the mode of candidacy - that is, whether legislators 
simultaneously stand for election in both tiers or whether they only pursue one type of mandate (Bawn and Thies 2003; Zittel 2012). Dual-listed candidates can be expected to respond to the incentives generated by the majoritarian tier, even if they wind up being elected off the party list (Pekkanen, Byblade, and Krauss 2006). Running an individualized constituency campaign not only increases a candidate's chances of winning the more prestigious district seat, it also increases the likelihood of obtaining a more secure list position in future elections (Patzelt 2007; Zittel and Gschwend 2008). In addition, the campaign strategies of district representatives in mixed systems may well be even more personalized than those of legislators in pure SMD systems. In the latter system, legislators are the sole incumbents running in their district and face less resourceful challengers. In mixed systems, on the other hand, the incumbency effect is less strong: members elected in the second tier often end up 'shadowing' the district member who defeated them by organizing and soliciting casework (Lundberg 2007; Carman and Shephard 2007). With the feeling of other incumbents breathing down their necks, these district members will have to invest even more resources to bolster up their personal reputation in order to win the harsh competition over personal votes.

'Pure' or 'strong' preferential systems constitute the opposite end of the continuum. Legislators' incentives to pursue an individualized campaign are expected to be strongest when voters may cast one or more preference votes and nominal votes alone determine the order in which seats are allocated to candidates (Karvonen 2004; Shugart 2008). Intra-party preference voting, by definition, rules out voters' ability to rely solely on the shared party label as a readily available voting cue and requires legislators to set themselves apart from copartisan competitors in constituents' minds (Shugart, Valdini, and Suominen 2005). It is the assumption that incentives to cultivate a personal vote increase with the scope of intra-party competition, that is the number of candidates running under the party label per seat available 
(Carey and Shugart 1995). ${ }^{2}$ But, intra-party competition may be more black-and-white than a matter of degree: as few as one or two viable co-partisan competitors may prompt legislators to court a personal vote and increasing that number may only marginally affects the strength of these incentives (André, Depauw, and Deschouwer 2012). Both single-transferable vote and open-list PR systems fall within the category of strong preferential systems. In PR-STV, all candidates appear on the ballot in alphabetical order, discouraging voters to organize their ordinal preferences along party lines. In this highly competitive electoral environment, copartisans compete with each other for the first preferences of loyal party voters and undecided voters, and for the lower preferences of voters committed to other parties (Gallagher 2008). In open-list PR systems, on the other hand, candidates are grouped on ordered or (partly) alphabetical party lists. As the party-preferred ranking of candidates is merely an advice voters may choose to disregard, a high list position does not translate into a formal electoral advantage (Katz and Bardi 1980).

In 'weak' preferential systems or flexible-list PR elected representatives should be more inclined to cultivate a personal reputation than legislators in non-preferential systems, but less so than legislators in strong preferential systems. The allocation of seats to candidates is based on the number of preference votes they gathered as well as on their position on the party list (Marsh 1985; Karvonen 2004). Therefore, the electoral utility of running an individualized campaign to a large extent depends on the number of preference votes required to 'leapfrog' past higher ranked candidates and voters' propensity to utilize their possibility to express one or more candidate preferences (Marsh 1985; Katz 1986; Norris 2006). A good personal score in any case increases a legislator's probability of being assigned to a legislative, executive, or party post with high visibility and raises his chances of obtaining a more secure position near the top of the list at the next election. 
Another component of electoral system design besides ballot structure that the literature puts front and centre is district magnitude. Though the number of seats to be allocated in a district can take a wide range of values, existing research has focused by and large on the binary distinction between single-seat and multi-seat districts (see e.g. Heitshusen, Young, and Wood 2005). It has been the dominant assumption that the personal vote incentives facing legislators in multi-seat districts are weaker than those facing legislators in single-seat districts. Where each legislator represents a distinct geographical area, the accountability linkage is strongest (Lancaster 1986; Scholl 1986; Pilet, Freire, and Costa 2012). On the one hand, elected representatives can directly be rewarded for promoting constituents' interests. Blame, on the other hand, is equally indivisible: constituents can easily sanction their representative for shirking their demands (Buck and Cain 1990; Bowler and Farrell 1993). In the context of dyadic representation (Thomassen and Andeweg 2004), as a result, developing a favourable personal reputation among constituents is key to a legislator's electoral success. In multi-seat districts, by contrast, representation has a more collective, partisan dimension. Legislators have the opportunity to either free-ride on the achievements of other representatives or pass them the buck. They, thereby, obfuscate the ability of rationally ignorant voters to monitor their actions and assign them credit and blame. Competition for votes, as a consequence, will quickly become less personalized as districts grow in magnitude (Wessels 1999; Pilet, Freire, and Costa 2012), in turn decreasing the electoral utility of constituency service and voting dissent in parliament.

Carey and Shugart (1995) famously added, however, that district magnitudes' effect is contingent upon the ballot structure. That is, the balance legislators strike between candidatecentred and party-centred vote-seeking strategies depends on the interaction between district 
magnitude and ballot structure. Personal vote incentives are expected to decrease with magnitude in closed-list systems, but increase with magnitude in systems with intra-party candidate choice. As the number of candidates running in a district increases in systems with fixed party lists, on the one hand, voters will increasingly rely on parties' labels to reach an 'informed' decision. Strengthening the party's collective reputation gains relevance under these circumstances. In systems where preference votes are effective in determining the order of intra-party seat allocation, on the other hand, voters increasingly turn to candidate-specific information in the voting booth. The more co-partisan candidates a legislator competes against, the harder it is to distinguish himself from the throng, and the more effort he will have to put into developing a personal reputation.

\section{Data}

The study of how electoral rules shape legislators' incentives to cultivate a personal or party reputation among constituents has largely been hindered by the unavailability of appropriate data (Shugart 2008). Comparative research is scarce and empirical studies typically resort to various - often aggregate-level - proxies. To explore how electoral rules shape legislators' personal-vote incentives and how these incentives translate into legislative behaviour, we rely on the extensive data collection efforts of the IAP PARTIREP project. The cross-national legislator survey covers fifteen national and fifty-eight regional parliaments in a range of European democracies. The selected parliaments, table 1 indicates, map onto different electoral system contexts in terms of electoral formula and ballot structure. District magnitude also varies widely across and generally even within cases - ranging from single-member districts to at-large region or nationwide districts. In some countries, different systems are 
combined to elect the legislators of a single parliament. In others, a different set of rules applies across levels of government and/or across regions. Variation in the response rate across cases, moreover, is not systematically related to the type of electoral system in use.

\section{[table 1]}

Members of the UK House of Commons and the French National Assembly are elected in single-seat districts respectively using a 'first-past-the-post' system and two-round majority system, respectively. Multi-seat districts with closed party lists are employed in Austria (for the upper tiers), France (for the regional assemblies), Italy (for the Camera dei Deputati and the Tuscan regional council), Israel, Norway ${ }^{3}$, Portugal, and Spain. The mixed electoral systems used in Germany, Hungary, Scotland, and Wales combine single-member districts and closed party lists. Strong preferential systems are found in Ireland (PR-STV), Italy (some regional councils), Poland, and Switzerland (open-list PR). But, there is substantial variation in the way voters can express a preference for individual candidates. In Poland, voters have to cast a single preference vote. Voters' choice of candidates is similarly constrained to one in Calabria, Lazio, and Lombardia. ${ }^{4}$ Two candidates can be selected in Campania and three in Valle d'Aosta. In Switzerland, by contrast, voters have two options: they may support a party list without indicating a candidate preference or they may cast as many preference votes as there are seats to be filled in the district. They can, moreover, vote for candidates of different parties (i.e. panachage) and/or vote for the same candidate twice (i.e. cumulative voting). Flexible-list systems, finally, are used in Austria, Belgium, and the Netherlands, but here too there are important differences in the method by which preference votes may alter the party's predetermined list ranking. In Austria ${ }^{5}$ and the Netherlands ${ }^{6}$, candidates reaching a particular quota of preference votes are elected regardless of their list position - provided of course their 
party has won sufficient seats. The remaining seats are allocated in the order candidates appear on the list (Andeweg 2008; Müller 2008). In Belgium, on the other hand, half of the votes cast for the party list (i.e. ballots without a candidate preference) are transferred to the highest ranked candidates until they clear the electoral quota. When the supply of list votes in exhausted, the process of intra-party seat allocation proceeds in the order of preference votes (De Winter 2008). ${ }^{7}$

\section{Electoral Rules and Campaign Strategies}

To capture legislators' incentives to cultivate a personal or party reputation, we build on Zittel \& Gschwend's $(2008,988)$ notion of campaign norms. The question in the PARTIREP survey assessing whether legislators "subjectively seek personal votes" was worded as follows:

\footnotetext{
"To retain their seat in the Parliament, Members of Parliament often face hard choices. How would you choose to allocate your limited resources? Would you choose to spend more effort and money on achieving the goal on the left-hand side, would you choose to spend more effort and money on the goal on the right-hand side, or would the allocation of resources to both goals be about equal?" A scale was offered ranging from 1 [a personal campaign] to 5 [a party campaign].
}

To ease interpretation of the results, the dependent variable was trichotomized and reversed: a value of ' 1 ' indicates a party-centred campaign, ' 3 ' indicates an individualized campaign strategy and '2' reflects a combination of both campaign styles. ${ }^{8}$ Table 2 presents the proportion of legislators in each of the three categories and shows the distribution of legislators' preferred campaign strategy by country and by ballot type. Even though there exist substantial variation in legislators' campaign norms, the figures underline a strong 
partisan component in the process of representation in Europe: 41 per cent of all legislators place themselves at the party-centred end of the continuum and 26 per cent gravitates towards the centre of the scale. ${ }^{9}$ But, electoral rules seem to matter in shaping a legislator's perceived utility of personal and party reputations in securing re-election. Elected representatives in countries with non- or weak preferential systems clearly prefer party-centred campaigns (e.g. Austria, Israel, the Netherlands, Norway, Portugal, Spain), whereas in countries with strongpreferential electoral rules (e.g. Ireland, Poland), the importance of personal campaigning is emphasized. In Germany and Hungary legislators, it seems, try to keep a balance between person and party in response to mixed electoral incentives. In case distinct rules are applied at different levels of government, however, percentages aggregated at the country-level might obscure within-country variation. The same picture crystalizes when the data are sorted by ballot type. More than one in two legislators elected in closed-list systems favours cultivating the party's collective reputation, whereas approximately two in five legislators elected in strong preferential systems actively seek personal votes. As expected, the two 'hybrid' systems fall somewhere in between 'pure' open and closed systems. Elected representatives in mixed-member systems tend to gravitate towards the middle and candidate-centred end of the scale, while those in flexible-list systems run more party-intensive campaigns.

[table 2]

To isolate the effect of electoral rules, we estimate partial proportional odds models (Williams 2006), which is the most parsimonious estimation technique to analyse a three-category ordinal dependent variable. ${ }^{10}$ This type of model relaxes the parallel lines assumption only for those independent variables violating the assumption, uncovering their differential effect across categories of the dependent variable. Constrained variables have one line of estimates 
in table 3 and their interpretation does not differ from interpreting ordered logit coefficients. Unconstrained variables, on the other hand, have two lines of estimates: the first line represents the coefficient for campaigns with at least some personal component (2 and 3) in contrast with party-focussed campaigns (1); the second line displays the coefficient for a predominantly individualized campaign strategy (3) in contrast with categories 1 and 2 . As it is not inconceivable that there are country differences in campaign styles, standard errors are clustered at the country-level. ${ }^{11}$

In testing the effect electoral rules have on the balance legislators strike between cultivating personal and party reputations, it is important to acknowledge that a number of other factors will shape the focus of their campaign strategy that need to be controlled for in the analysis. First, a legislator's perceived ideological distance from his party should increase the attractiveness of developing a distinct personal profile (Zittel and Gschwend 2008). About 43 per cent of the legislators in the sample fully share their party's ideological values and platform. Their self-placement on an eleven-point left-right scale does not deviate from the score they assigned their party. Another 37 and 14 per cent perceive a distance of respectively one and two scale points. Second, the campaign focus of legislators affiliated to right-wing political parties might be more personal in nature than that of left-wing party representatives. Party ideologies on the right of the political spectrum are often characterized as individualistic, whereas leftist ideologies tend to promote collectivism. Third, members of governing parties can be expected to pursue more individualized campaigns than those in opposition parties. The discrepancy between campaign promises and unredeemed expectations typically results in vote loss for governing parties - mid-term being the nadir of popularity (e.g. Van Der Eijk 1987). In this uncongenial re-election context, legislators may try to protect themselves from broader partisan swings by putting more emphasis on one's 
personal characteristics and achievements as compared to the party's collective record (Cain, Ferejohn, and Fiorina 1987; Kam 2009). Fourth, elected representatives of large mainstream parties will likely favour more candidate-centred campaigns. While small and niche parties lack local embedment, mainstream parties have a well-developed organization at the grassroots. These local structures and networks facilitate legislators' efforts in developing and maintaining high visibility and name recognition among constituents (Zittel and Gschwend 2008). In line with Ezrow's (Ezrow 2010, 12) definition, political parties belonging to the Social Democratic, Liberal, Christian Democratic, and Conservative party families are coded as mainstream. $^{12}$

The analysis further controls for a legislator's seniority. Veteran legislators have entered the protectionist stage of their career and try to consolidate the measure of trust and political support they have established among constituents over the years (Fenno 1978; Norton and Wood 1993). In addition, seniority and apprenticeship go hand in hand: senior parliamentarians are more likely to be assigned posts in parliament, in the committees, in the party, and possibly in the executive (Johannes 1980; Heitshusen, Young, and Wood 2005). The number of years a legislator has served in parliament should therefore be negatively related to his propensity to pursue an individualized campaign. A final control we add to the model is a dichotomous variable indicating regional parliaments. Members of regional assemblies are generally elected in districts with smaller constituent/representative ratios which should result in more direct contact (Patzelt 2007; Curtice and Shively 2009). Candidate-centred campaign strategies can therefore be expected to be more common at the lower levels of government. We now turn to the results of the multivariate analysis.

[table 3] 
The results presented in table 4 provide strong support for the main hypothesis: personal-vote seeking through individualized campaign strategies is markedly more valuable to legislators in open-list systems as compared to those elected on fixed party lists. Legislators' predicted probability of cultivating a personal reputation among constituents increases by 17 per cent when preference votes are the sole criterion for allocating seats to candidates. ${ }^{13}$ The probability of running a party-centred campaign, on the other hand, decreases from .54 in closed-list systems to .33 in open-list systems, a change significant at the .05 level. But no support is found for Carey and Shugart's (1995) oft-cited hypothesis that the effect of district magnitude is contingent upon the ballot structure. Legislators' incentives to pursue a personintensive campaign in open-list systems do not increase with the scope of intra-party competition. District magnitude, on the contrary, has an invariably negative effect in all list types as demonstrated by the multiplicative interaction terms included in model 2 . This effect is, however, largely driven by districts with a magnitude of one (in a similar vein, see Pilet, Freire, and Costa 2012). A legislator's predicted probability of seeking out personal votes decrease by 19 per cent when multiple seats are allocated in the district. When isolating single-member districts in the analysis, moreover, we can no longer be sure at any level of statistical significance that legislators' campaign norms become increasingly party-centred as magnitude grows (model 3). That is, an increase in district magnitude from 1 to 2 seats is more consequential for legislators' behaviour than an increase from 21 to 22 for instance. As the number of (co-partisan) competitors grows, voters become increasingly unable and unwilling to learn about the characteristics, stands, and records of individual candidates. Even in open-list systems, legislators' personal vote incentives may therefore quickly be outweighed by the increasing efforts and resources needed to communicate a personal reputation to voters. 
The campaign focus of legislators in flexible-list systems seems to be somewhat more candidate-centred than in closed-list systems (8\%) but less so than in open-list systems (9\%) though these changes in predicted probabilities cannot be distinguished from zero at conventional levels of statistical significance. This group of systems seems to be too heterogeneous a category to generate a univocal effect. Not only do these systems vary from each other based on the details of the electoral rules (e.g. quota or transfer system), but the same set of formal rules may present legislators with different incentives and constraints depending on their position on the party list and the actual number of preference votes required to alter their rank. To scale these flexible-lists systems on the continuum between 'pure' closed and open-list systems requires a case-by-case judgement accounting for possible intra-system variation (Shugart, Valdini, and Suominen 2005; Shugart 2008) that is beyond the scope of this chapter.

Table 3 further reveals that, in contrast with closed-list systems, legislators' campaign strategies in mixed-member systems are considerably more candidate-intensive. The predicted probability of running a highly individualized campaign is approximately 12 per cent higher in mixed systems - an increase significant only at a more lenient level of .10. But, legislators primarily end up in the middle category responding to the competing incentives generated by the different tiers. They have more than 50 per cent chance of combining both campaign styles, a probability which is 22 per cent higher than in closed-list systems. Mixed systems appear to be more than a mere sum of their parts. The mode of candidacy seems to be an important cause of spill-over effects, explaining why legislators in mixed systems more frequently opt to bolster up their personal reputation. 
When restricting the analysis to mixed-member systems in table 4, we find clear differences in the campaign focus of successful district candidates, defeated district candidates elected on the party list, and 'list-only' candidates. For district members, the personal vote incentives generated by the SMD tier always override the incentives emanating from the PR component even if they are granted a secure position on the party list. They are 41 per cent more likely to run a predominantly candidate-centred campaign than list-only members and 20 per cent more likely to do so than list members simultaneously pursuing a district mandate. On the other hand, the electoral utility of an individualized campaign to dual-listed candidates that were rejected by the district in which they stood for election depends on their party affiliation. Only candidates from the large mainstream parties that have a reasonable chance of winning district seats and have well-developed local branches are more inclined to favour personal over party reputations. Small and niche parties, by contrast, field candidates in the SMD races merely to increase the party's vote share in the PR (Cox and Schoppa 2002; Ferrara and Herron 2005). The widespread use of split-ticket voting turns their district candidates into 'hopeless' contestants (Patzelt 2007). But in return, these candidates are rewarded with a higher position on the party list. As a result, the incentives facing small party candidates standing simultaneously in both tiers strongly resemble those facing list specialists: cultivating the party's collective reputation is much more important is securing re-election than seeking out personal votes.

[table 4]

Over and above the effect of electoral rules, party-related factors have an impact on the candidate or party-centred nature of a legislator's campaign. Personal vote-seeking strategies are more appealing to legislators identifying more loosely with their party. Legislators feeling 
more distant from their party in ideological terms are significantly more likely to favour personal over party reputations. But the effect is rather small substantively: the predicted probability of running a predominantly individualized campaign is only 3 per cent lower for the strongest identifiers than for legislators perceiving a one-point deviance between their own and their party's position on the left-right scale and 12 per cent lower for those perceiving a three-point deviance. In addition, representatives from left-wing parties are considerably more party-centred in their campaign focus than those from right-wing parties. Changing a party's position on the left-right scale from 3 to 7 - that is the mean minus and plus one standard deviation - decreases a legislators likelihood of prioritising a more collective party campaign by 13 per cent. Elected representatives from governing parties, moreover, have a slightly higher likelihood of pursuing a candidate-intensive campaign. A favourable personal reputation might help individual legislators to compensate for the generally lower levels of party popularity at the end of the term either by winning personal votes or by giving the party a human face in the district. Personal campaigning, finally, is also more common among legislators affiliated to the large mainstream parties with established local structures and vital grassroots but the effect does not reach conventional levels of statistical significance. Seniority and the level of government hardly affect a legislator's campaign choices.

\section{Campaign strategies, constituency service and party discipline}

In the previous section we linked electoral rules to legislators' campaign norms as they perceive them - arguably a more direct measure of personal vote incentives. In the second step of the analysis, we assess whether and to what extent differences in the candidate- or 
party-centred nature of campaign strategies translate into attitudinal and behavioural differences in the way legislators perceive their representative tasks. We will focus on two oft-cited indicators of personal and partisan vote-seeking: legislators' commitment to constituency service on the one hand, and to upholding party discipline on the other. Based on the extensive literature reviewed in the first sections of our chapter, we hypothesise that legislators who prioritize cultivating their personal reputation in their campaigns will be more eager to show constituents that they care about their needs. As a result, personal vote-seekers are expected to focus on their constituencies to a greater extent than those pursuing predominantly party-centred campaigns. Additionally, we expect them to be more relaxed in their attitudes toward party discipline as well: they should be more willing to desert the party opinion when it conflicts with the interest of their districts. Since one cannot be entirely certain about the direction of causality, we use symmetric measures to analyse the correlation between legislators' campaign norms and their degree of constituency orientation.

The relation of personal vote-seeking to constituency service is twofold: on the one hand, it relates to the strength of a legislator's constituency orientation and it shows in the activities carried out in district, on the other hand. First, we find a significant relationship between the campaign strategies legislators pursue and the focus of representation they choose. The PARTIREP MP survey asked legislators to indicate on a seven-point scale how important they consider it to promote the views and interests of all the people who voted for their party and of the people in their constituency. ${ }^{14}$ Table 5 shows the importance the average legislator in the sample attaches to promoting the interests of the two different groups of people. In addition, party promoters put greater emphasis on representing the party voters, whereas legislators pursuing a more individualized campaign favour to look after the people in their districts. Overall averages (5.77 and 5.7 points) indicate that respondents rated both categories 
generously: both the party electorate and the constituents seem exceptionally important to represent. For this reason, the relative importance of party and constituency representation was calculated by a simple division of ratings to show whether individual campaigners are indeed more inclined to focus on their constituencies. The results support the initial hypothesis: personal vote-seekers actually consider the promotion of constituency interests more important than both party campaigners and those who try to balance between the two strategies.

[table 5]

Second, legislators' decision as to whether or not to engage in certain constituency-oriented activities that bolster up their reputation and visibility among constituents also varies under different campaign strategies. Personal vote-seekers are significantly $(\mathrm{p}<.05)$ more likely to "attend (or send out letters on the occasion of) weddings, wedding anniversaries, and funerals", "send out personal newsletters", and "meet with local businesses and action groups" and they do so more frequently than members prioritizing a more party-intensive campaign. Additionally, representatives favouring personal over party reputation appear to be more likely to "meet with (small parties of) constituents in their private home to talk about their wants and needs", "hold surgeries", "advertise (...) constituency work services" and “publicize (...) successes in attracting business and obtaining government grants for the local area" as well. But the frequency for these activities is the same under the different campaign strategies.

[table 6] 
Personal vote-seeking is not only connected to legislators' behaviour in the district, but it has implications for party discipline in parliament as well. We measure dissent on the attitudinal level using the concept of the style of representation, capturing a legislator's willingness to desert the party line. Representatives were asked, in case of conflict, to trade off their party's opinion with their personal judgment on the one hand and their voters' opinion on the other. Table 6 shows the distribution of answers over the different campaign strategies. Figures indicate that the average legislator would choose to vote in line with the party's opinion in case of conflict with either his/her own opinion or with that of the voters: 60.4 per cent of all representatives said that they would follow the party, even if this implies setting aside their personal judgment. The partisan preference is even stronger when it comes to choosing between the voter and the party: 64.7 per cent thinks that they should vote with the PPG. The results demonstrate the same pattern when we examine the distribution of answers over the different campaign strategies. In every category, the party's opinion prevails. There are, however, significant differences in the dominance of the party-centred answers. 50 per cent of the personal vote-seekers think that they should take their own opinion as a guideline, and 42.5 per cent would stick with the voters' will in case of a conflict. Both percentages exceed the proportion of those who would vote against the party in the other two groups. This indicates that personal vote-seekers are more willing to desert the party lines than members pursuing party-centred campaigns.

\section{Conclusion}

In the recent wave of reform debates, it has often been argued that the quality of political 
representation depends not only on the ideological congruence between the represented and those acting on their behalf, but also on the strength of the representative relationship (e.g. Norris 2006; Shugart 2008; Freire and Meirinho 2012). This chapter has sought to contribute to this topical discussion by studying, on an unprecedented scale, how electoral systems affect the legislators' vote-seeking strategies and behavioural patterns. Electoral institutions, it was demonstrated, affect legislators' campaign strategies. Legislators elected on the basis of their preference votes alone are considerably more likely to pursue an individualized campaign that distinguishes themselves from co-partisan competitors than those elected in closed-list systems. Hybrid systems, on the other hand, fall somewhere in-between open and closed-list systems: legislators elected in flexible-list systems and mixed-member systems tend to combine both campaign strategies. As districts increase in magnitude, however, legislators' predicted probability of running a candidate-centred campaign decreases. More than being a difference of degree, the effect of district magnitude is a difference of kind: legislators' campaign strategies in multi-seat districts are more party-focused than in single-seat districts.

Legislators' decision as to the type of campaign to pursue, moreover, has important consequences for what they do in and outside parliament in-between election campaigns. Electoral rules that incentivize legislators to run a personalized campaign not only increase the amount and quality of services offered to constituents, but also enhance members' potential to desert the party lines. Personal vote-seeking was found to increase the value of being congruent with constituents' preferences in terms of voting behaviour in parliament, whenever there is a conflict between voters' and party's preferences. In sum, the recent trend towards systems that allow for effective intra-party choice might the constituentrepresentative relationship, but might also increase the potential dissolution of party unity and thereby challenge the responsible party model that as dominant theory explaining 
representation and governance in contemporary Europe. Perhaps the problem here is one of balance and admitting that the 'best of both worlds' might not be entirely possible.

\section{References}

Andeweg, Rudy B. 2008. "The Netherlands: The Sanctity of Proportionality.” In The Politics of Electoral Systems, ed. Michael Gallagher and Paul Mitchell, 491-510. Pbk. Ed. Oxford: Oxford University Press, USA.

André, Audrey, and Sam Depauw. 2013. "District Magnitude and Home Styles of Representation in European Democracies." West European Politics forthcoming.

André, Audrey, Sam Depauw, and Kris Deschouwer. 2012. “Legislators' Local Roots: Disentangling the Effect of District Magnitude." Party Politics (October 9). doi:10.1177/1354068812458617.

http://ppq.sagepub.com/content/early/2012/10/08/1354068812458617.

Bawn, Kathleen, and Michael F. Thies. 2003. “A Comparative Theory of Electoral Incentives Representing the Unorganized Under PR, Plurality and Mixed-Member Electoral Systems." Journal of Theoretical Politics $15 \quad$ (1): 5-32. doi:10.1177/0951692803151001.

Blumenthal, Sidney. 1980. The Permanent Campaign: Inside the World of Elite Political Operatives. Boston: Beacon Press.

Bowler, Shaun, and David M. Farrell. 1993. "Legislator Shirking and Voter Monitoring: Impacts of European Parliament Electoral Systems Upon Legislator-Voter Relationships." JCMS: Journal of Common Market Studies 31 (1): 45-70. doi:10.1111/j.1468-5965.1993.tb00447.x. 
Buck, J. Vincent, and Bruce E. Cain. 1990. "British MPs in Their Constituencies.” Legislative Studies Quarterly 15 (1): 127-143. doi:10.2307/440006.

Butler, Patrick, and Neil Collins. 2001. "Payment on Delivery - Recognising Constituency Service as Political Marketing." European Journal of Marketing 35 (9/10) (October 1): 1026-1037. doi:10.1108/EUM0000000005956.

Cain, Bruce, John Ferejohn, and Morris Fiorina. 1987. The Personal Vote: Constituency Service and Electoral Independence. Cambridge: Harvard University Press.

Carey, John M, and Matthew Soberg Shugart. 1995. "Incentives to Cultivate a Personal Vote: A Rank Ordering of Electoral Formulas.” Electoral Studies 14 (4) (December): 417439. doi:10.1016/0261-3794(94)00035-2.

Carey, John M. 2007. "Competing Principals, Political Institutions, and Party Unity in Legislative Voting." American Journal of Political Science 51 (1): 92-107. doi:10.1111/j.1540-5907.2007.00239.x.

Carman, Christopher, and Mark Shephard. 2007. "Electoral Poachers? An Assessment of Shadowing Behaviour in the Scottish Parliament." The Journal of Legislative Studies 13 (4): 483-496. doi:10.1080/13572330701663587.

Cox, Karen E., and Leonard J. Schoppa. 2002. "Interaction Effects in Mixed-Member Electoral Systems Theory and Evidence From Germany, Japan, and Italy." Comparative Political Studies 35 (9): 1027-1053. doi:10.1177/001041402237505.

Crisp, Brian F., Kathryn M. Jensen, and Yael Shomer. 2007. "Magnitude and Vote Seeking." Electoral Studies 26 (4): 727-734. doi:10.1016/j.electstud.2007.08.001.

Curtice, John, and W. Phillips Shively. 2009. "Who Represents Us Best? One Member or Many?” In The Comparative Study of Electoral Systems, ed. Hans-Dieter Klingemann, 171-192. Oxford; New York: Oxford University Press. 
Van Der Eijk, Cees. 1987. “Testing Theories of Electoral Cycles.” European Journal of Political Research 15 (2): 253-270. doi:10.1111/j.1475-6765.1987.tb00876.x.

Ezrow, Lawrence. 2010. Linking Citizens and Parties: How Electoral Systems Matter for Political Representation. Comparative Politics. New York, NY: Oxford University Press.

Farrell, David M. 2001. Electoral Systems: a Comparative Introduction. New York: St. Martin's Press.

Fenno, Richard F. 1978. Home Style: House Members in Their Districts. Longman Classics in Political Science. $\quad$ Boston: Little, Brown. http://books.google.ca/books?id=p4UrAQAAMAAJ.

Ferrara, Federico, and Erik S. Herron. 2005. "Going It Alone? Strategic Entry Under Mixed Electoral Rules." American Journal of Political Science 49 (1): 16-31. doi:10.1111/ajps.2005.49.issue-1, 10.1111/j.0092-5853.2005.00107.x.

Freire, André, and Manuel Meirinho. 2012. "Institutional Reform in Portugal: From the Perspective of Deputies and Voters Perspectives." Pôle Sud - Revue De Science Politique 36 (1): 107-125.

Gallagher, Michael. 2008. "Ireland: The Discreet Charm of PR-STV." In The Politics of Electoral Systems, ed. Michael Gallagher and Paul Mitchell, 511-532. Pbk. Ed. Oxford: Oxford University Press, USA.

Heitshusen, Valerie, Garry Young, and David M. Wood. 2005. "Electoral Context and MP Constituency Focus in Australia, Canada, Ireland, New Zealand, and the United Kingdom.” American Journal of Political Science 49 (1) (January 1): 32-45. doi:10.1111/ajps.2005.49.issue-1, 10.1111/j.0092-5853.2005.00108.x. 
Herron, Erik S, and Misa Nishikawa. 2001. "Contamination Effects and the Number of Parties in Mixed-superposition Electoral Systems.” Electoral Studies 20 (1): 63-86. doi:10.1016/S0261-3794(00)00002-0.

Johannes, John R. 1980. “The Distribution of Casework in the U. S. Congress: An Uneven Burden.” Legislative Studies Quarterly 5 (4): 517-544. doi:10.2307/439572.

Kam, Christopher J. 2009. Party Discipline and Parliamentary Politics. 1st ed. Cambridge: Cambridge University Press.

Karvonen, Lauri. 2004. "Preferential Voting: Incidence and Effects." International Political Science Review 25 (2): 203-226. doi:10.1177/0192512104041283.

Katz, Richard S. 1986. “Intraparty Preference Voting.” In Electoral Laws and Their Political Consequences, ed. Bernard Grofman and Arend Lijphart, 85-103. New York: Agathon Press.

Katz, Richard S., and Luciano Bardi. 1980. "Preference Voting and Turnover in Italian Parliamentary Elections.” American Journal of Political Science 24 (1) (February 1): 97-114. doi:10.2307/2110926.

Lancaster, Thomas D. 1986. "Electoral Structures and Pork Barrel Politics." International Political Science Review 7 (1) (January 1): 67-81. doi:10.1177/019251218600700107. Lundberg, Thomas Carl. 2007. Proportional Representation and the Constituency Role in Britain. Basingstoke: Palgrave Macmillan.

Marsh, Michael. 1985. "The Voters Decide?: Preferential Voting in European List Systems.” European Journal of Political Research 13 (4): 365-378.

Mayhew, David R. 1974. Congress : the electoral connection. New Haven: Yale University Press. 
Mitchell, Paul. 2000. "Voters and Their Representatives: Electoral Institutions and Delegation in Parliamentary Democracies.” European Journal of Political Research 37 (3): 335351. doi:10.1023/A:1007025105144.

Müller, Wolfgang C. 2008. "Austria: A Complex Electoral System with Subtle Effects.” In The Politics of Electoral Systems, ed. Michael Gallagher and Paul Mitchell, 397-416. Pbk. Ed. Oxford: Oxford University Press, USA.

Norris, Pippa. 2006. "Ballot Structures and Legislative Behavior: Changing Role Orientations via Electoral Reform.” In Exporting Congress?: The Influence of the U.S. Congress on World Legislatures, ed. Timothy J. Power and Nicol C. Rae, 157-184. Pittsburgh, PA: University of Pittsburgh Press.

Norton, Philip, and David M. Wood. 1993. Back from Westminster: British Members of Parliament and Their Constituents. Lexington, MA: University Press of Kentucky.

Patzelt, Werner J. 2007. “The Constituency Roles of MPs at the Federal and Länder Levels in Germany." Regional \& Federal Studies $17 \quad$ (1): 47-70. doi:10.1080/13597560701189610.

Pekkanen, Robert, Benjamin Byblade, and Ellis S. Krauss. 2006. "Electoral Incentives in Mixed-Member Systems: Party, Posts, and Zombie Politicians in Japan." The American Political Science Review 100 (2): 183-193. doi:10.2307/27644343.

Pilet, Jean-Benoit, André Freire, and Olivier Costa. 2012. "Ballot Structure, District Magnitude and Constituency-Orientation of MPs in Proportional Representation and Majority Electoral Systems.” Representation $48 \quad$ (4): $\quad 359-372$. doi:10.1080/00344893.2012.720880.

Scholl, Edward L. 1986. "The Electoral System and Constituency-Oriented Activity in the European Parliament.” International Studies Quarterly 30 (3) (September 1): 315332. doi:10.2307/2600420. 
Searing, Donald. 1994. Westminster's World: Understanding Political Roles. Cambridge: Harvard University Press.

Shugart, Matthew Søberg. 2008. "Comparative Electoral Systems Research: The Maturation of a Field and the New Challenges Ahead." In The Politics of Electoral Systems, ed. Michael Gallagher and Paul Mitchell, 25-55. Pbk. Ed. Oxford: Oxford University Press, USA.

Shugart, Matthew Søberg, Melody Ellis Valdini, and Kati Suominen. 2005. "Looking for Locals: Voter Information Demands and Personal Vote-Earning Attributes of Legislators Under Proportional Representation." American Journal of Political Science 49 (2): 437-449. doi:10.1111/j.0092-5853.2005.00133.x.

Shugart, Matthew Soberg, and Martin P Wattenberg, ed. 2001. Mixed-member electoral systems the best of both worlds? Oxford: Oxford University Press. http://site.ebrary.com/id/10283339.

Steenbergen, Marco R., and Bradford S. Jones. 2002. "Modeling Multilevel Data Structures.” American Journal of Political Science 46 (1) (January 1): 218-237. doi:10.2307/3088424.

Thomassen, Jacques, and Rudy B. Andeweg. 2004. "Beyond Collective Representation: Individual Members of Parliament and Interest Representation in the Netherlands." The Journal of Legislative Studies 10 (4): 47-69. doi:10.1080/1357233042000322463.

Wessels, Bernhard. 1999. "Whom to Represent? Role Orientations of Legislators in Europe." In Political Representation and Legitimacy in the European Union, ed. Hermann Schmitt and J. J. A. Thomassen, 209-234. Oxford ; New York: Oxford University Press.

Williams, Richard. 2006. “Generalized Ordered Logit/partial Proportional Odds Models for Ordinal Dependent Variables.” STATA Journal 6 (1): 58-82. 
De Winter, Lieven. 2008. “Belgium: Empowering Voters or Party Elites?” In The Politics of Electoral Systems, ed. Michael Gallagher and Paul Mitchell, 417-432. Pbk. Ed. Oxford: Oxford University Press, USA.

Zittel, Thomas. 2012. "Legislators and Their Representational Roles: Strategic Choices or Habits of the Heart?” In Parliamentary Roles in Modern Legislatures, ed. Magnus Blomgren and Olivier Rozenberg, 101-120. Oxford: Routledge.

Zittel, Thomas, and Thomas Gschwend. 2008. "Individualised Constituency Campaigns in Mixed-Member Electoral Systems: Candidates in the 2005 German Elections.” West European Politics 31 (5): 978-1003. doi:10.1080/01402380802234656. 
Table 1: Electoral Rules in 15 European democracies

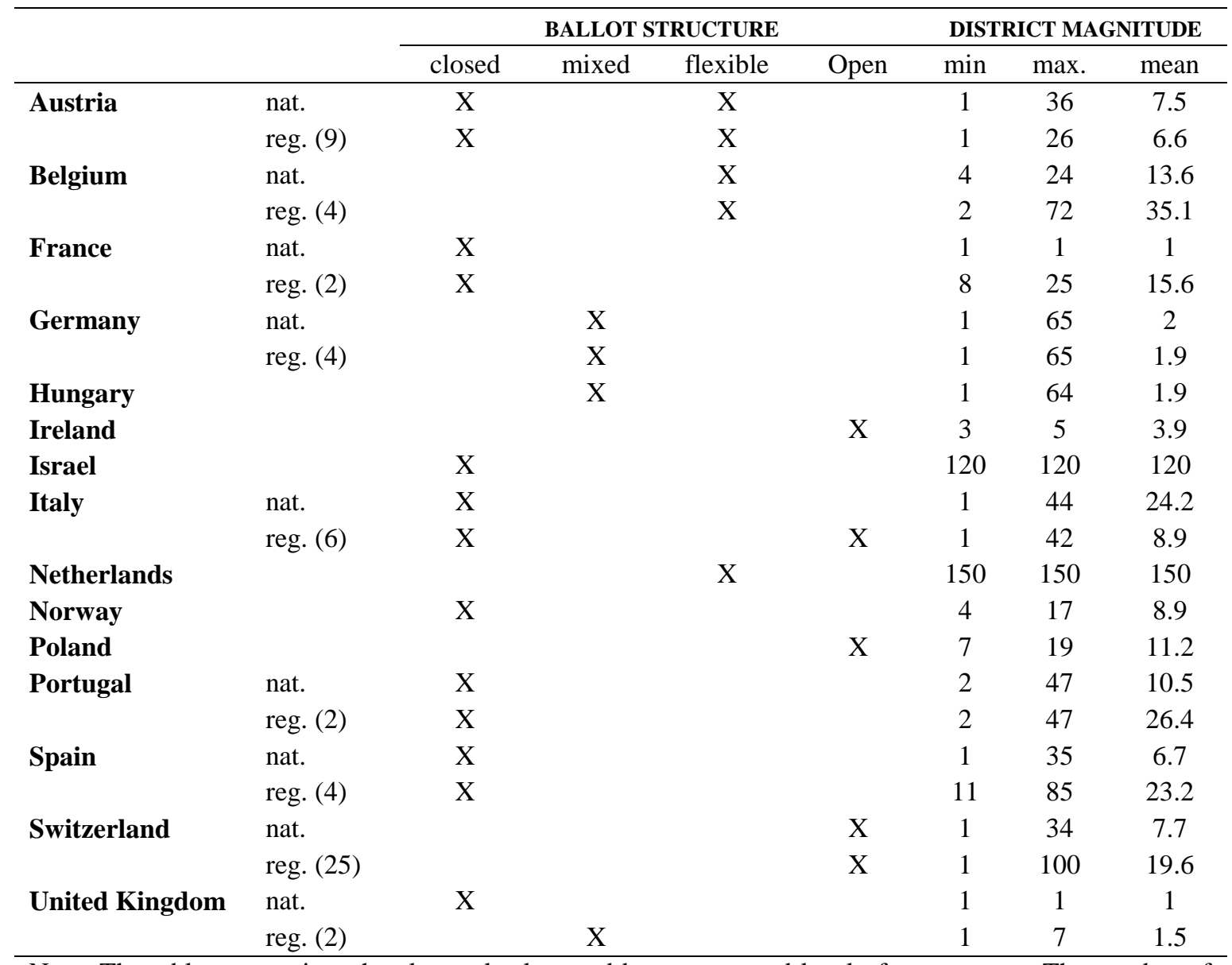

Note: The table summarizes the electoral rules used by country and level of government. The number of regional parliaments is indicated between brackets. Closed denotes the non-preferential systems; mixed the mixed-members systems; flexible the weak preferential systems; and open the strong preferential systems. Source: PARTIREP MP survey. 
Table 2: Campaign strategies in 15 European countries

\begin{tabular}{rccc}
\hline & \multicolumn{3}{c}{ Party versus Personal Campaigns } \\
\cline { 2 - 4 } Country & $\mathbf{1}$ & $\mathbf{2}$ & $\mathbf{3}$ \\
\hline Austria & 50.08 & 32.32 & 17.61 \\
Belgium & 29.52 & 37.74 & 32.74 \\
France & 19.22 & 26.44 & 54.34 \\
Germany & 19.07 & 45.21 & 35.73 \\
Hungary & 22.24 & 49.62 & 28.14 \\
Ireland & 16.19 & 32.4 & 51.42 \\
Israel & 41.59 & 29.76 & 28.65 \\
Italy & 45.62 & 21.96 & 32.42 \\
Netherlands & 73.93 & 9.84 & 16.23 \\
Norway & 77.95 & 18.94 & 3.11 \\
Poland & 8.37 & 39.22 & 52.41 \\
Portugal & 53.95 & 37.55 & 8.49 \\
Spain & 72.21 & 21.4 & 6.39 \\
Switzerland & 38.41 & 30.66 & 30.93 \\
United Kingdom & 22.29 & 42.07 & 35.64 \\
\hline Ballot structure & & & \\
\hline Closed & 54.98 & 26.08 & 18.94 \\
Mixed & 20.16 & 46.69 & 33.15 \\
Flexible & 46.01 & 30.47 & 23.52 \\
Open & 30.03 & 32.16 & 37.81 \\
\hline Overall average & 40.81 & 32.84 & 26.35 \\
\hline E
\end{tabular}

Note: Entries are the frequencies in each category (percentages). Source: PARTIREP MP survey. 
Table 3: Electoral Rules and Campaign Strategies

\begin{tabular}{|c|c|c|c|c|c|c|}
\hline & \multicolumn{2}{|c|}{ MODEL 1} & \multicolumn{2}{|c|}{ MODEL 2} & \multicolumn{2}{|c|}{ MODEL 3} \\
\hline & $\mathrm{b}$. & s.e. & $\mathrm{b}$. & s.e. & $\mathrm{b}$. & s.e. \\
\hline \multirow{2}{*}{ Open-list } & .899 & $(.349)^{* * *}$ & 1.441 & $(.538)^{* * *}$ & 1.059 & $(.362) * * *$ \\
\hline & & & 1.368 & $(.533)^{* * *}$ & & \\
\hline \multirow{2}{*}{ Flexible-list } & .468 & $(.431)$ & .625 & $(.666)$ & .542 & $(.409)$ \\
\hline & & & .205 & $(.706)$ & & \\
\hline \multirow{2}{*}{ Mixed-member } & 1.546 & $(.352)^{* * *}$ & 1.744 & $(.417)^{* * *}$ & 1.397 & $(.279)^{* * *}$ \\
\hline & .687 & $(.431)$ & .577 & $(.533)$ & .453 & $(.360)$ \\
\hline \multirow{2}{*}{ Open-list*DM } & & & -.449 & $(.268)^{*}$ & & \\
\hline & & & -.519 & $(.337)$ & & \\
\hline \multirow{2}{*}{ Flexible-list*DM } & & & -.122 & $(.531)$ & & \\
\hline & & & .195 & $(.383)$ & & \\
\hline \multirow{2}{*}{ Mixed-member*DM } & & & -.165 & $(.263)$ & & \\
\hline & & & .124 & $(.388)$ & & \\
\hline \multirow{2}{*}{ District Magnitude (log) } & -.588 & $(.172)^{* * *}$ & -.486 & $(.275)^{*}$ & -.151 & $(.224)$ \\
\hline & & & -.627 & $(.361)^{*}$ & & \\
\hline Single-member district & & & & & 1.094 & $(.360)^{* * *}$ \\
\hline \multirow{2}{*}{ Ideological Proximity } & .141 & $(.061)^{* *}$ & .138 & $(.060)^{* *}$ & .135 & $(.062)^{* *}$ \\
\hline & .254 & $(.069) * * *$ & .249 & $(.070) * * *$ & .250 & $(.071)^{* * *}$ \\
\hline Party's left-right position & .143 & $(.039) * * *$ & .146 & $(.039) * * *$ & .135 & $(.036) * * *$ \\
\hline Governing Party & .208 & $(.091)^{* *}$ & .217 & $(.085)^{* *}$ & .234 & $(.079) * * *$ \\
\hline Mainstream Party & .370 & $(.261)$ & .372 & $(.259)$ & .355 & $(.253)$ \\
\hline Seniority (in years) & .012 & $(.008)$ & .012 & $(.008)$ & .009 & $(.008)$ \\
\hline Regional Parliament & -.070 & $(.118)$ & -.057 & $(.132)$ & -.025 & $(.137)$ \\
\hline Constant (1) & -.827 & $(.515)$ & -.973 & $(.548)^{*}$ & -1.420 & $(.471)^{* * *}$ \\
\hline Constant (2) & -2.323 & $(.570)^{* * *}$ & -2.274 & $(.676)^{* * *}$ & -2.927 & $(.524) * * *$ \\
\hline $\mathrm{N}$ & 1996 & & 1996 & & 1996 & \\
\hline Log pseudo-likelihood & -1971.94 & & -1968.98 & & -1956.81 & \\
\hline $\mathrm{LR}(\mathrm{df})$ & 372.13 & $(12)^{* * *}$ & 378.04 & $(12)^{* * *}$ & 402.40 & $(12)^{* * *}$ \\
\hline Nagelkerke $r^{2}$ & 0.192 & & 0.195 & & 0.206 & \\
\hline
\end{tabular}


Table 4: The Mode of Candidacy and Campaign Strategies in Mixed-Member Systems

\begin{tabular}{|c|c|c|c|c|}
\hline & \multicolumn{2}{|c|}{ All parties } & \multicolumn{2}{|c|}{ Mainstream parties } \\
\hline & & s.e. & b. & s.e. \\
\hline \multicolumn{5}{|c|}{ mode of candidacy (ref. list-only candidate) } \\
\hline Successful district candidate & 1.590 & $(.385)^{* * *}$ & 2.179 & $(.490)^{* * *}$ \\
\hline Defeated district candidate & .545 & $(.385)$ & 1.408 & $(.501)^{* * *}$ \\
\hline Constant (1) & -.414 & $(.594)$ & .134 & $(.860)$ \\
\hline Constant (2) & -2.676 & $(.614) * * *$ & -2.807 & $(.871)^{* * *}$ \\
\hline $\mathrm{N}$ & 357 & & 245 & \\
\hline Log pseudo-likelihood & -348.06 & & -226.68 & \\
\hline $\mathrm{LR}(\mathrm{df})$ & 56.28 & $(8) * * *$ & 37.60 & $(9) * * *$ \\
\hline Nagelkerke $r^{2}$ & 0.166 & & 0.164 & \\
\hline
\end{tabular}

Note: The table displays the parameter estimates and robust standard errors (in parentheses) of a partial proportional odds model. Controls for ideological distance, governing party, year of first entry, regional parliament and the ratio between district and list seats are not displayed. ${ }^{*} \mathrm{p} \leq .10 ; * * \mathrm{p} \leq .05 ;{ }^{* * *} \mathrm{p} \leq .01$, using two-tailed t-values. Source: PARTIREP MP survey. 
Table 5: The average importance of promoting the interests of the different groups of people

\begin{tabular}{|c|c|c|c|}
\hline & \multicolumn{3}{|c|}{ Importance of promoting the interests of... } \\
\hline & $\begin{array}{c}\text { all the people who } \\
\text { voted for his/her party }\end{array}$ & $\begin{array}{l}\text { all the people in his/her } \\
\text { constituency }\end{array}$ & $\begin{array}{l}\text { relative importance } \\
\text { (constituency/party) }\end{array}$ \\
\hline \multicolumn{4}{|l|}{ Campaign strategy } \\
\hline Party & $5.96(1.171)$ & $5.56(1,420)$ & $.986(.506)$ \\
\hline Both & $5.77(1.201)$ & $5.79(1.257)$ & $1.054(.477)$ \\
\hline Personal & $5.47(1.342)$ & $5.79(1.476)$ & $1.147(.681)$ \\
\hline Overall average & $5.77(1.243)$ & $5.7(1.387)$ & $1.051(.552)$ \\
\hline Significance & $\mathrm{p}<.01$ & $\mathrm{p}<.01$ & $\mathrm{p}<.01$ \\
\hline Eta & .157 & .081 & .117 \\
\hline
\end{tabular}

Note: Entries are mean values, standard deviations in parentheses. Source: PARTIREP MP survey. 
Table 6: Dissent in parliament under different campaign strategies

\begin{tabular}{|c|c|c|c|c|}
\hline & \multicolumn{2}{|c|}{$\begin{array}{l}\text { If his/her opinion does not correspond } \\
\text { with the opinion of the party, the MP } \\
\text { should vote according to the opinion } \\
\text { of the... }\end{array}$} & \multicolumn{2}{|c|}{$\begin{array}{l}\text { If his/her opinion does not correspond } \\
\text { with the opinion of the voters, the MP } \\
\text { should vote according to the opinion of } \\
\text { the... }\end{array}$} \\
\hline & MP & party & Voters & party \\
\hline \multicolumn{5}{|l|}{ Campaign strategy } \\
\hline Party & 31.3 & 68.7 & 31.1 & 68.9 \\
\hline Both & 41.4 & 58.6 & 34.9 & 65.1 \\
\hline Personal & 50 & 50 & 42.5 & 57.5 \\
\hline Overall & 39.6 & 60.4 & 35.3 & 64.7 \\
\hline Significance & \multicolumn{2}{|c|}{$\mathrm{p}<.01$} & \multicolumn{2}{|c|}{$\mathrm{p}<.01$} \\
\hline Kendall's tau-c & \multicolumn{2}{|c|}{-.164} & \multicolumn{2}{|c|}{-.095} \\
\hline
\end{tabular}

Note: Entries are the frequencies in each category of campaign strategies (percentages). Source: PARTIREP MP survey. 


\section{Notes}

1 The German, Scottish and Welsh parliaments use a two-tiered system with single-member plurality at the lowest level, whereas at the time the data was collected, the Hungarian mixed system complemented a tworound majority system with two PR tiers. In all parliaments (incl. the Hungarian one), voters cast two ballots: one for a candidate in the first tier and one for a party list in the second tier. The ratio of district to list seats varies across parliaments however: the German Bundestag, Brandenburg, Rhineland-Palatinate, and Thuringia have a 50:50 ratio, Lower Saxony a 65:35 ratio, Wales a 67:33 ratio, Scotland a 57:43 ratio, and Hungary a 46:54 ratio. Only in Wales dual candidacies are not allowed. There are further differences in the linkage mechanism between tiers, and the district magnitude, legal threshold, and electoral formula in the PR tier (Shugart and Wattenberg 2001).

2 Crisp et al. (2007) define the degree of intra-party competition as the ratio between the number of co-partisan competitors and the expected party magnitude.

3 The Norwegian electoral law allows voters to alter the list order of candidates or by striking out names. For these changes to take effect, more than half of the party electorate should indicate a preference for the same candidate. This has never occurred so far.

4 Members of these regional councils use open-list PR, but a majority bonus is allocated to the coalition or party list elected for presidency.

5 For the Austrian Nationalrat, candidates running in the lowest tier need at least as many preference votes as half of the Land-level Hare quota or one sixth of the party vote in the district to be elected in defiance of the list order. In the second tier, candidates need to reach the full Hare quota. At the regional level, all parliaments use a flexible-list system in the lowest tier. Burgenland, Lower Austria, and Vienna use that system in the second tier as well. The quota specified vary widely.

6 In the Netherlands, candidates move to the top of the list when their preference votes reach 25 per cent of the Hare quota.

7 In Belgium, the 'eligibility threshold' equals the party's total district vote divided by the number of seats won plus one.

8 The scores of ' 4 ' and ' 5 ' on the original scale are recoded as ' 1 ', whereas the scores of ' 1 ' and ' 2 ' are collapsed in ' 3 '.

9 To correct the bias resulting from the inclusion of all Swiss cantonal parliaments, that high number of responses is down weighted to a level comparable with the responses in the other countries. We further 
correct for the over and underrepresentation of particular political parties by weighing the responses by the size of the parliamentary party in each parliament.

10 We use Williams' (2006) software package 'gologit2' in Stata.

11 The data have a multi-level structure with individual MPs nested in countries. Using clustered standard errors is a good way to correct for the non-independence of observations at the country-level. Clustering avoids inflated standard errors and decreases the likelihood of committing Type I errors (Steenbergen and Jones 2002).

12 In addition, a handful of parties that would be coded as mainstream based on party family, but that systematically receive a small share of the votes are added to the reference category (e.g. the FDP in Germany).

${ }^{13}$ To compute predicted probabilities as well as the 95 per cent confidence intervals for of discrete changes, continuous variables were fixed at their mean values (log of district magnitude=1.03; ideological distance $=0.87$; party's left-right position $=4.97$; number of years served in parliament=5.27). All dichotomous variables were set to zero, save for mainstream party.

14 For the sake of presentational purposes, equal distance between scale values is assumed. 